UDC $1 / 14$

Kadzhik M. OGANYAN,

Vladimir PYZH,

Sergey PETROV,

Karina K. OGANYAN

\title{
THE SELF-ORGANIZATION LAW OF INTERSUBJECTIVE IDEALS: THE PROBLEM OF CHAOS, ORDER, FREEDOM AND LIABILITY RELATIONSHIP*
}

\begin{abstract}
The relevance of the study is due to the need of theoretical and methodological interpretation of the relationship between freedom and responsibility, chaos and order in the frame of the synergetic philosophy of history ( $\mathrm{SPH}$ ) in implementing the law of self-organisation of intersubjective ideals under new social conditions.

Keywords: synergetic philosophy of history; the meaning of life; intersubjective ideal; social order; the creative role of chaos; ideological self-organization; harmony of responsibility (order) and freedom (chaos); change of social ideals; dramatic optimism; the principle of determination and rationality.
\end{abstract}

The aim of the article is to prove scientifically the logical transition from the global interaction of chaos and order in nature to their global interaction in society leading to overcoming the global conflict between human freedom and responsibility and achieving complete harmony between them through the law of selforganization of intersubjective ideals.

The leading approach to investigating this problem is applying the heuristic function of the synergetic philosophy of history to implement

\footnotetext{
The article is the outcome of the scientific research on the issues and problems of synergetic philosophy of history and a logical continuation of the article (Branskij, Oganyan, K. M. \& Oganyan, K. K., 2018) and the achievements of St. Petersburg Synergetic Scientific School guided by Professor V. Branskij (19302017).
}

the law of self-organization of intersubjective ideals.

The main results of the article. A new interpretation of the concepts "synergetic philosophy of history", "self-organization of intersubjective ideals" suggesting the creation of fundamentally new values is given. Long rotation within the "golden" circle leads the participant of the world history beyond this circle and adds a global meaning (movement towards the super attractor, as a materialized spiritual value of the highest rank) to his activity. At the same time, the participant in this process perceives the "meaning of life", remaining within the framework of a consistent scientific worldview (not breaking off with the principles of determinism and rationality).

It is stated that the fluctuations between to- 
talitarianism and anarchism are not unsystematic. Their objective and necessary result is the harmonization (in the average long-term perspective) of freedom and responsibility (caused by the balancing of social chaos and social order). The specific nature of the super attractor is to balance the creative role of both order and chaos.

It is also put forward that within the framework of the synergetic philosophy of history, the real essence of this limit is revealed: The SPH considers it to be a quantitative measure of harmony between chaos and order in the general philosophical sense of these concepts. Such a measure can be interpreted as a "golden mean" between chaos and order and an indicator leading to the achievement of this harmony.

The authors provide a detailed justification for the fact that it is the trade-off between freedom and responsibility that results in the law of self-organisation of intersubjective ideals. The consequence of this law is the stochastic fluctuations of the self-organizing system (humanity) between the craving for totalitarianism and the desire for deconstruction (modern anarchism); self-organization acting as a potential means of harmonization of an individual and society; philosophical significance of the ideological conflict between K. Marx (XIX century) and K. Popper (XX century.) on the possibility of long-term social predictions.

Materials can be used to develop new courses on the synergetic philosophy of history, social synergy, synergetic theory of values, synergetic theory of man, the theory of self-organization of intersubjective ideals.

\section{Introduction}

The creative team members of St. Petersburg Synergetic Scientific School investigated various aspects associated with the synergetic philosophy of history and their results ${ }^{1}$ initiated this article.

Methodological problems of the synergetic of globalization: Oganyan, K. M. (2007). Metodologicheskie problemi teorii globalizacii (Methodological Problems of the Synergetic Theory of Globalization, in Russian). Social Sciences and Modern times, 2; Oganyan, K. M. (2017). Methodological Analysis of the Scientific Research. NOEMA, XVI, 81-93; Oganyan, K. M., Branskij, V. P., Oganisyan, A. O., \& Djidjian, R. Z. (2018). Metodologicheskii analiz genezisa nauchnoi teorii: vidi estestvennonauchnogo znania $i$ ikh vzaimosvaz'. Ocherki o Leningradskoi ontologicheskoi i Erevanskoi logikoargumentacionnoi shkolax (Methodological Analysis of the Genesis of a Scientific Theory: Types of Natural Science Knowledge and Their Relationship. Essays on the Leningrad Ontological and Yerevan Logical-Argumentative Schools, in Russian). SPb.: Publishing house of SPbGEU.

The laws of production, consumption, preservation and development of values: Oganyan, K. M. (2013). Zakonomernosti potrebleniya cennostei i potrebitelskie avtokolebaniya. Roli modi $\mathrm{v}$ potreblenii cennostei (Regularities of Consumption of Values and Consumer Automation. The Role of Fashion in the Use of Values, in Russian). Successes of Modern Natural Science, 2, 107-112; Oganyan, K. M., Sahakyan, A. K., Pokrovskaya, N. N., Bakhshyan, A. Zh. (2013). Cennostnye orientacii v trudovom povedenii i kross-kulturnoe issledovanie trudovoi migracii (Value Orientations in Labor Behavior and Cross-Cultural Research of Labor Migration, in Russian). Yerevan: EDIT PRINT.

The synergetic theory of ideals: Oganyan, K. M., Branskij, V. P. (2014). Zakon relevantnosti $i$ integracii idealov povedencheskix stereotipov (The Relevance and Integration Law of Behavioral Stereotype Ideals, in Russian). Vestnik KRSU, 14(6), 70-79.

The problems of the controlled chaos: Pyzh, V. V. (2017). The Role of UNESCO in Protecting Sports Integrity and Preserving Sports Ideals. Proceedings of the International Conference on Modern Research in Science and Technology, (pp. 596-607). Scientific public organization "Professional Science"; Pyzh, V. V. (2018). The Controlled Chaos Doctrine and Securi- 
Let us consider the results provided by a new approach to the relationship between freedom and responsibility in the framework of the synergetic philosophy of history. The main problem in the philosophy of activity is how to harmonize its freedom with responsibility (see Oganyan, K. M., \& Oganyan, K. K., 2017 ; Oganyan, K. M., \& Oganyan, K. K., 2017 ). Generally, within the frame of philosophy, it is the coordination of activities between chaos (freedom of choice) and order (regulation of actions) when the creative role of order seems to be incompatible with the creative role of chaos.

The experience of world history shows that rigid rules imposed on any activity lead to totalitarianism, and liberation from any kind of restrictions (rules) - to deconstructionism (modern anarchism). As is known from history, the first one leads to strangulation of freedom, and the second- to its depreciation. Thus, without freedom of creativity, the creation of new values becomes impossible. Only an account for the law of self-organization of intersubjective ideals enables to get a clear answer to the question posed. The general recipe for choosing between craving for freedom and craving for order is to study the interaction of the main selection factors within a self-organizing system (thesaurus, detector and selector) (see Branskij, Oganyan K.M., \& Pozharskiy, 2009). The philosophical significance of the law of self-organization of intersubjective ideals therefore is in the solution of Prigogine's paradox (Branskij, Oganyan K.M., \& Pozharskiy, 2009, pp. 155-164) (an explanation of how the simultaneous movement of mankind to maximum freedom and maximum order (maximum

ty of Modern Russia, in Russian). Modern Periodicals in the Context of Communicative Processes. The Future of Eurasia (Media and Political Discourse), 3(12), 38-52. (G. S. Melnik, B. Ya. Misonzhnikov, I. A. Scherbo, Eds.). SPb.: SPbSU. organization and responsibility) is possible. Hence, from the point of view of the synergetic philosophy of history (SPH), the cult of freedom is just as unacceptable as the one-sided cult of order. It is the law of self-organization of intersubjective ideals that shows how one can avoid permissiveness (complete arbitrary rule in human actions) within a strictly scientific outlook. At the same time, as soon as the thinker is trying to eliminate this arbitrariness within the unscientific (mystic) philosophy, he immediately encounters with the theodicy problem ${ }^{2}$.

A rational compromise between freedom and responsibility (the "golden dream" of all civilized politicians) is based on the law of selforganization of intersubjective ideals ${ }^{3}$. This law is closely related to the problem of long-term social forecasting. As we know, K. Marx formulated the global law of the mankind development to the world proletariat dictatorship (see Marx, 1926; Marx, 1982), and K. Popper - a similar law of mankind's movement to the global civil society (Popper, 1993; Popper, 1992). The first concept absolutized the social order, and the second - social chaos. The first insisted on the existence of an objective social law that allows predicting a distant social future; the second - on the absence of such a law and impossibility of reliable predictions of the global social future. Both concepts encountered fundamental difficulties in their practical application. Neither attempts to achieve the world dictatorship of the proletariat (K. Marks, V. Lenin, etc.), nor at-

2 Theodicy is the justification of God the Almighty for the world evil (see Branskij, Oganyan K.M., \& Pozharskiy, 2009, pp. 265-272).

3 It is this law that, if we use the mythological language of R. Wagner in his operatic cycle "The Ring of the Nibelung", turns the Nibelungs ("children of the mist", that is, people with not yet formed ideology) into knights of the round table ("soldiers of the white swan," i.e. ideologically mature people). 
tempts to build a global liberal civil society (Fukuyama, 2007) have been a decisive success ${ }^{4}$.

By the beginning of the $21^{\text {st }}$ century, it has become clear that the problem was not actually in absolutizing global social order (the highest social responsibility) or global social chaos (maximum social freedom), but in achieving harmony of both (the way of overcoming the so-called Prigozhin paradox - the simultaneous movement of mankind to both maximum responsibility and maximum freedom).

\section{The Main Consequences of Self-Organization Law of Intersubjective Ideals}

This law results in fundamental conflicts in human relationships and simultaneously creates the conditions for the resolution of these conflicts.

The main factor at work in such conflicts is the differentiation of human behavior into good and evil. From the SPH viewpoint, good is an act corresponding to an intersubjective ideal, and evil is an act incompatible with this ideal. Hence, the relativity of the difference between these concepts becomes obvious: if good is an act that corresponds to an ideal, then evil is an act corresponding to an anti-ideal (for example, killing a human being during military operations directed by well-intentioned patriotic motives or killing a person for the purpose of robbing him in peacetime). It is obvious that the division of actions into "good" and "evil" is connected with the splitting of the intersubjective ideal into an ideal and an anti-ideal. SPH views morality as a system of behaviour rules dictated by a specific intersubjective ideal. Therefore, the primary con-

4 One-sided cult of order (law-abiding responsibility) leads to suffocation of freedom; one-sided cult of chaos ("freedom") - devaluation of freedom. cept here is not the system of moral norms, but the ideal that determines this system.

The self-organizing system fluctuations between good and evil lead in the long run to its balancing between totalitarianism (the cult of order and responsibility) and anarchism (the cult of chaos and freedom). The desire for totalitarianism or anarchism in the society is by no means an accidental phenomenon or the fruit of some irrational malicious intent: totalitarianism is the natural defensive reaction of the selforganizing system from anarchism, and the latter from totalitarianism. The moments of good and evil are present both in totalitarianism and in anarchism (therefore, any one-sided laudatory or one-sidedly negative assessments of both, from a scientific point of view, are not justified).

An equally remarkable consequence of the self-organization law of intersubjective ideals is the explanation of the erotic polarization of any developing society based on this law, i.e. dividing it into men and women. The direct cause of such polarization is the erotic polarization of any biogeocenosis (its division into males and females).

The reason for this process is the advantage that sexual reproduction of living beings has in comparison with the non-sexual one. It allows to solve an apparently impossible task: to combine the creative role of order (restrictions - taboos on erotic contacts) with the creative role of chaos (the removal of certain limitations, due to the possibility of expanding casual acquaintances the so-called irrational love "if not from the first, then at least from the second glance"). Apparently, due to this prominent peculiarity of sexual reproduction, selection and superselection give it preference as compared with other forms of reproduction. The described resolution of the contradiction between chaos and order in sexual 
reproduction makes clear the fundamental nature of the opposition and interaction of male and female principles, both in nature and society.

SPH is identified as follows. Self-organization is in no way reduced to the philistine endless pursuit of utilitarian values ${ }^{5}$ : it involves the creation of fundamentally new values (the embodiment of uniqueness). Graphically, this can be represented as the unfolding of the Wagnerian gold ring of Nibelung (absolute value symbol) into the "golden spiral", explored for the first time by Swiss mathematicians Bernoulli. The "golden" spiral, unlike many other spirals, is "logarithmic" and contains a singular point (called in mathematics "singularity", not of a local but of a global nature). Therefore, a long rotation within the "golden" circle sooner or later leads a participant of world history beyond this circle and gives its activity a global meaning (movement towards a super-attractor, as a materialized spiritual value of the highest rank). At the same time, the participant in this process acquires the "meaning of life", remaining within the framework of a consistent scientific worldview (not breaking with the principles of determinism and rationality) (see Branskij, 2014, p. 25).

Thus, the required compromise between freedom and responsibility yields the law of selforganization of intersubjective ideals. As a result of this law, as it already noted, is the stochastic fluctuations of the self-organising system (humanity) between the craving for totalitarianism and the urge for deconstruction (modern anarchism). Consequently, a scientific approach to the origin of totalitarianism and anarchism differs significantly from the naive political approach popular in the mass media of the $20^{\text {th }}$ cen-

These values are of primary interest for an international inhabitant of all epochs and peoples who is ready to sacrifice for his satisfaction. tury. Totalitarianism does not arise by chance, as a result of some evil irrational intent - this is a natural reaction to anarchism; similarly anarchism is just a natural reaction to totalitarianism. But the fluctuations between totalitarianism and anarchism are not unsystematic (and therefore are not meaningless). Their objective and necessary result is harmonization (in the average long-term perspective) of freedom and responsibility (caused by the balancing of social chaos and social order). The specific nature of the super attractor is to balance the creative role of both order and chaos. That is why the move to the super-attractor leads to the already mentioned motto in human actions: "Fight and seek, find and do not give up!"’6.

As we have already seen, unlike Nietzsche, who at the end of the $19^{\text {th }}$ century was one of the first to speak of "the death of the gods", Hegel used a very beautiful metaphor - "The Minerva's Owl starts its flight only with the onset of twilight". This image means something much more subtle and profound: intersubjective ideals never completely die, but "plunge into twilight" (fall into decay after unsuccessful attempts at their full realization, lose their former popularity; compare the fate of the Catholic ideal in Ger-

The words of the English romantic poet A. Tennyson (XIX century), taken as an epitaph to the burial of the heroic English Antarctic explorer Captain R. Scott (the XX century) on the Antarctic coast.

Here the popular words of the famous hit come to mind: "Everything is illusory in this raging world; there is only an instant - and hold on to it, there is only an instant between the past and the future - it is that is called life!" From the scientific worldview, such "impressionistic" eschatology is opposed by synergistic eschatology $(\mathrm{SPhH})$ : the latter insists not on instantainity, but on sustainability (strength) of life, replacing the ephemeral instant between the past and the future by long-lasting harmony between them. Therefore, the words of the mentioned hit should be modified in the following way: "Everything is illusory in this raging world; take care and hold on tight. There is a precarious instant between the past and the future: it is that is called life!" 
many in the middle of the $17^{\text {th }}$ century and in France at the end of the $18^{\text {th }}$ century; the Orthodox ideal in Russia in the first half of the $20^{\text {th }}$ century; the communist ideal in Russia at the end of the $20^{\text {th }}$ century, etc.). Hence, in view of the fundamental difference between truth and ideal, the triumph of the ideal also does not prove its truth, as well as its collapse - its falsity.

The historical significance of private-human ("relative") ideals is not in proving their "truth" or "falsity", but in verifying their greater or lesser availability as a means of transforming society under the given historical conditions. It is important not to confuse the ascertaining (factual) and key knowledge: privatehuman ("relative") ideals are building material for the formation and realization of the universal "absolute" ideal. The defenders of aggressive criticism of the absolute ideal should also moderate their polemical fervour, as well as the opponents of the absolute truth: if the complete collapse of absolute truth (as incontrovertible within its applicability) leads to world incognizability, then the complete collapse of the absolute ideal - to meaninglessness of human existence. Although absolute truth and absolute ideal should not be identified, but this does not mean that one can ignore the connection between them. From the SPH point of view, absolute truth is a means of realizing absolute ideal. Consequently: precisely because the absolute truth cannot be reached in the final historical period, the absolute ideal is not achievable that time.

\section{A brief overview of the SPhH general} structure. It is obvious that unlike many philosophical speculations on the "meaning of life", SPH has a very harmonious logic connected with the reconciliation of natural and humanitarian thinking (this logic should be called even "steel" rather than "iron"). In the era of aggressive attacks on the principles of determinism and rationality, such logic cannot but attract attention to itself. To understand the core of the matter of this logic, it is useful to discuss it shortly.

The most important conclusion the SPH comes to is the following: "the meaning of the world (social) history is revealed not by science but by ideology, but the vehicle it uses can only be understood with the help of science". Any attempts to understand this issue without science in advance doom the scientist to empty chatter and "commonplace" exchange of emotions. To avoid such a course of "discussion", one must compare the history of formation and attempts to implement different ideologies without any emotional prejudices (avoiding any biassed assessments). At the same time, under "ideology" one must understand ideology, i.e., a clear doctrine of some kind of intersubjective ("social" and not only individual) ideal that determines the behavior of a large human group (a strategic program of action of such a group is associated with a long historical perspective and aimed at preserving or changing the social system within which this group is).

The representatives of materialistic dialectics failed to observe the parallel between the development of knowledge directed towards absolute truth (as a result of the interaction of relative truths) and social activity towards the formation of the universal ("absolute") ideal (as a result of the interaction of relative ideals). In the twentieth century, these representatives did not find this parallel. However, if this parallel were to be found, everyone would be convinced that the communist ideal has no basis to claim the role of the universal ideal. Responsible party workers attributing absolute character to the communist ideal and mistakenly identifying the 
absolute ideal with absolute truth ${ }^{7}$, turned this ideal into something "divine" and began to consider any deviations from it as a state crime. Hence, it is clear what philosophical significance this global parallel has.

Thus, from the SPH point of view, it is impossible to confuse such concepts as "scientific ideology" and "scientific theory of ideology". The first is impossible in principle because ideology is not a doctrine of truth, but an ideal (ideology). And these are different concepts. Scientific ideology is as controversial as a "round square" or "roasted ice". On the contrary, the scientific theory of ideology (as an ideology) has a profound sense. The study of the history of different ideologies shows that all of them, depending on their attitude to hypothetical supernatural reality ${ }^{8}$, can be divided into three classes: 1) polytheism (all kinds of paganism); 2) monotheism (all kinds of religious denominations - Christianity, Islam, Judaism, Buddhism, etc.); 3) atheism (all kinds of variants of secular ideology). With all the difference, they have something in common: different interpretation of the concept of "ideal" (each interprets it as "holiness"). There are also various "intermediate" varieties, moreover as a result of self-organization of intersubjective ideals in the future, there may be ideological constructions of a much more complex nature, and very difficult for prediction.

Thus, from the SPH point of view, the meaning of history is implied in the notion of "moving to the superattractor". This process is

\footnotetext{
"...from the historicall viewpoint, any ideology is conditional but, of course, the fact that any scientific ideology (in contrast, for example, to the religious one) corresponds to objective truth". See (Lenin, 1958).

8 In the history of philosophy and the history of science, "supernatural" reality is usually understood as an objective reality that exists outside space and time and is not subject to any laws.
}

conceived as spontaneous, not pursuing any purpose (i.e., the process of non-teleological character). This interaction accounts for rational meaning of a historical concept fate. The chain of participants in this process, who adhere to different (and even opposite) ideological aims, makes it clear how the combination of the most sublime romanticism with the most sober realism in one process becomes possible. A note: romanticism is usually associated with the content of the ideal, and realism - with the way it is realized.

Although many philosophers (G. Hegel, N. Berdyaev, K. Jaspers, and others) characterized human history as a "graveyard of ideals", nevertheless, in the long run, the amazing "vitality" of these strange creatures (their ability to "resurrection to new life") was obvious. Considering the proximity of such philosophical concepts as "ideal" and "god" identified by L. Feuerbach, some philosophers (for example, F. Nietzsche) described the destruction of ideals as the "death of gods".

It turns out that the confusion and the seeming unpredictability of social events, that hinders scientific understanding of the global course of social history, has a certain regularity that gives order to seemingly complete social chaos. As it had already been pointed out, from the SPH point of view, the secret of it lies in

\section{the law of self-organization of intersubjec- tive ideals.}

The law of self-organization of intersubjective ideals, expanding the ability of mankind to control cosmic processes, and, consequently, prevent dangerous cosmic catastrophes for it can make the future of mankind much more secure than it seems at the present level of our knowledge and technical capabilities. Even large-scale ideological differences in the ranks of 
the future mankind on the methods of preventing cosmic catastrophes dangerous for the very existence of mankind, can be successfully overcome within the framework of the law of self-organization of intersubjective ideals. A very important point is the self-organization of humanity in the face of a seemingly alien and hostile cosmos can be considered as a very resourceful self-defense.

From the above concept, it becomes clear that the most important discovery in the field of philosophical knowledge obtained by the SPH is in the so-called eschatological paradox: "if a person became immortal, his life would lose meaning". This paradox leads to the following practical recommendation: the highest happiness for a harmoniously developed personality is the struggle to achieve the highest spiritual values - absolute truth, absolute good and absolute beauty.

In the works by Branskij V. P. (see Branskij, 2017) the synergistic philosophy of history ( $\mathrm{SPH})$ is opposed to any historical pessimism, and gives way to the so-called dramatic optimism (not understating the difficulties of human existence, and not exaggerating them). Although this optimism honestly recognizes the importance of such philosophical concepts as sacrifice, but at the same time he is aware of the inseparability of SPH from such a philosophical concept as heroic humanism. The fact is that real (and not only imaginary) heroism is impossible without humanism, but civilized (highly developed, not naive, mature) humanism is impossible without heroism. However, the drama of human existence, in particular, lies in the fact that heroism and humanism in history often turn out to be in deep contradiction with each other. This contradiction is often ignored by the supporters of the so-called "abstract" humanism and "abstract" heroism. Without taking into account the scientific theory of ideology as an ideology, this contradiction cannot be eliminated. But for its effective elimination it should not be hushed up (pretending that such a contradiction supposedly does not exist).

The conclusion is in the twentieth century due to the intensive development of scientific and technological progress (and cultural progress in general), gloomy predictions about the possible (in the near or distant future) death of human being, humanity and world culture were widespread (see Katsura, 2016). It is curious, however, that there is a happy ambiguity unnoticed by their defenders: the "death" of a human being, humanity and world culture can mean the transformation of a man into a superman, humanity into a super humanity, and culture into a super culture $^{9}$. But the correct understanding and fair assessment of such a transformation at the modern level of our knowledge is impossible without a thorough study of the synergistic philosophy of history (SPH). As the general SPH logic puts it, self-organization law of the "ideological" animals community does not only exclude the possibility of their global self-destruction (in the literal sense), but also their destruction by new (as yet unknown to us) space factors (due to the potentially infinite ability of such a self-organizing system as humanity to the invention and improvement of new means of self-defense). Consequently, the salvation of humanity (even in a hostile space) is possible without abandoning

9 Superman is the material embodiment of an absolute ideal of man; superhumanism - the material embodiment of the absolute ideal of humanity; and superculture is the material embodiment (the system of attractors) of the absolute ideal of culture (the system of absolute values, unlike all specific historical cultures, which were and are the systems of relative values). 
such worldview principles as determinism and the principle of rationality.

The concept of "sustainability" of the global self-organization of the universe leads to farreaching philosophical conclusions. As is known from the history of classical physics, the development of the latter led the physicist W. Thomson (Kelvin) to the concept of the "thermal death" of the Universe. He showed that in the case of a closed finite model of the Universe, such a fundamental law of classical physics as the second law of thermodynamics (according to which the entropy of the Universe should tend to the maximum) should lead to the conclusion that there is a natural tendency to stop all macroscopic processes in the Universe. He called this state "thermal death". But this tendency is valid only for the closed (non-interacting with unobserved residue) Universe. But having in view the materialistic ontological model of physical reality (which classical physics requires), we cannot admit the influence of any natural forces on the maximization of global entropy. But then the maximization of global entropy cannot be stopped and the "thermal death" of the material Universe becomes inevitable ${ }^{10}$. It is not difficult, however, to understand that the tendency of the global thermodynamic system to a state that we called "superattractor" should be called the "fourth principle of thermodynamics". This state (in contrast to the three standard "principles" in classical thermodynamics) can only be inherent in open systems (and, therefore, is beyond the scope of ordinary classical thermodynamics). It should be the result of stabilizing its oscillations

10 In this case, the system's "thermal death" can be avoided only in one of two ways: 1) by "dropping" excess entropy into the external environment; or 2) by converting this excess into additional negentropy inside the system, compensating for the excess entropy. (between increasing and decreasing), but not of maximizing the entropy. This means that in the long run, each increase in entropy provokes an equal decrease, and decrease - an equal increase. As a result of such oscillations, complete harmony between chaos and order is gradually achieved. Under the assumptions made, such harmony does not depend on whether the cosmological model is finite or infinite. In the case of an infinite system, despite the lack of interaction with the environment, the openness of the system, apparently, is provided by its ability to selfinteraction (interaction with itself).

Hence, from the foregoing is clear that considering the movement to the super attractor as the fourth law of thermodynamics takes the researcher not only beyond inanimate nature (the laws of physics in the proper sense), but also beyond living nature (laws of biology): we find ourselves within the scope of social laws (social reality, i.e., culture in the widest sense). Indeed, in this case, self-organization includes not only the self-organization of cosmic matter, but also the field of any human knowledge and desires. Here we meet with the law of self-organization of intersubjective ideals [we find ourselves in the interaction area of self-organization of matter and "spirit" (the stream of rational and emotional information)]. That is why the discussion of the movement to the super attractor inevitably leads a researcher, to a new philosophy of history (SPH), which equally evaluates the activity of a historical object and a historical subject. At the same time, any onesided exaggeration of the role of material and ideal factors is excluded (any bias towards objective or subjective factors in the social process). Actually speaking, self-organization is harmonization of these factors (which is in the very concept of self-organization). The idea of self- 
organization is based on the interaction of material and ideal factors. Therefore, the primacy of one of them (characteristic of classical historical materialism) is deliberately excluded.

The scientific significance of the synergetic philosophy of history becomes obvious when solving the twentieth century historical mystery, which was first clearly described by one of the leading experts on criticism of the communist ideology Z. Brzezinski. In his fundamental anticommunist work "The Great Failure", he wrote in 1989: "Communism will remain in people's memory first of all, as the most unusual political and intellectual delusion of the twentieth century" (Brzezinski, 1989, p. 13). If the communist ideal is just a "delusion", its phenomenal success in such dissimilar countries like Russia and China remains incomprehensible, where the mentioned ideal has taken root in human minds for more than 70 years? The Bzezinski enigma described in the SPH framework has a strictly scientific explanation without any deviations from the principles of determinism and rationality. To

find an explanation of the charismatic effect of spreading a new ideal, we must rely on the concept of self-organization of social reality associated with it - the law of self-organization of intersubjective ideals. This law assumes the dual (contradictory) nature of ideological selforganization. We are talking about this interaction of opposing ideals, which combines their collision (rivalry, opposition, competition) with their cooperation (solidarity, cooperation, assistance). For this reason, competing ideals can both interfere with each other's realization and help (synergistic effect). To properly understand the final results of a new ideal, one must take into account its relation to the old ideal (its interaction with the old ideal). Different old ideals can have different effects on new ideals. If the requirements of the new ideals coincide with some essential requirements of the old ones, the success in spreading new ideals in a society (charismatic effect based on the synergistic effect) will be guaranteed.

The old ideals seem to smooth favorable ideological way ${ }^{11}$ for the perception of new ideals. It is this role that the Orthodox ideal played in Russia with its image of Moscow as the third Rome (Berdyaev, 1990), which to some extent coincided with the Bolsheviks' preaching of the world revolution (freeing all classes from capitalist exploitation).

Similarly, in China, the Confucian ideal played a similar role considering the world state as a "big family", disburdening the oppressed colonial peoples from the imperialist exploitation (Mao Zedong, 2007). Huge popularity of such a foreign Western "plant" as a communist ideal in such countries as Russia and China in the twentieth century from the SPH viewpoint is easily explained by the powerful objective social base in the form of a multimillion-strong peasantry in these countries with its acute need to solve the agrarian problem tormenting it: "Every plowman must have his own field" (Sun Yat-sen). The thirst of this stratum for global liberation from all

11 Although the Marxism founders had high hopes for the success of the communist ideal in such developed capitalist countries as Western Europe and the USA, this ideal drew wide support in a completely different geographic region (Russia and China). As is clear from the foregoing, this is explained by the fact that the success of a new ideal requires a corresponding ideological ground prepared by the old ideal. Such a ground could have been prepared by the ideal that focused in the worldview not on the individual, but on the collective. Therefore, both the Western liberal ideal and Eastern Buddhism and Hinduism were not suitable enough to serve the social function that the advocates of collective solidarity (Orthodoxy and Confucianism) took up. It is curious that the religious status of the Orthodox ideal and the semi-atheistic Confucian did not materially manifest itself in the influence of these ideals on the communist ideal. 
forms of economic and political, national and colonial, class and racial oppression has been embodied in Lenin's idea of an alliance of the proletariat and peasantry ("industrial and agricultural workers of all countries, unite!" -the global call for the liberation of man from all forms of its exploitation by another man based on the destruction of private ownership of tools and means of production by a new type of state - the worldwide "dictatorship of the proletariat").

\section{Conclusion}

Although the communist ideal in its original Marxist version required a harmony of responsibility (order) and freedom (chaos), but gradually during attempts to implement it, it was modified in the style of one-sided craving for totalitarianism (cult of order). Gradually, this brainchild of refined intellectuals (Marx, Engels, Lenin, Trotsky, and etc.) began to turn towards the priority of responsibility to freedom, human duties to rights, etc. This did not happen by chance: the social basis of such an evolution was the duality (inconsistency) of that union of workers and peasants, which was the basis of the Bolshevik revolution in Russia.

The ideology of refined intellectuals could not help but differ from the ideology of poorly educated workers and peasants. The threat of a gradual abandonment of harmony of responsibility and freedom, and absolutisation of responsibility (and, thus, the cult of human duties compared to his rights) led to the victory of one of the most consistent totalitarian regimes in the history of mankind (Stalinism). A defense reaction from such a turn of events was an alternative movement to the so-called modern deconstructivism, with his wide use of the latest scientific and technological progress (new technologies, new energy sources, computerization, etc.) for rampant modern anarchism. But a natural balance between totalitarianism and anarchism (the Prigozhin paradox) results, ultimately, in a super atractor. The latter is the consequence of overcoming Prigozhin's paradox and the potentially endless search for a way out of the global crisis. The super attractor is the pointer to the location of this exit. Thus, the movement to the super attractor means not the "thermal death" of the Universe and the achievement of the maximum entropy, but the achievement of a certain similarity to the "earthly paradise" (figuratively speaking, the magic crystal of such paradise), which implies the achievement of the minimum of entropy. That is why the synergetic philosophy of history can, in principle, create the intellectual atmosphere of the so-called dramatic optimism.

So, from the SPH point of view, the meaning of history is the move to superattractor, i.e. search for a social structure capable of achieving complete harmony between chaos and order (freedom and responsibility). Two opposing global trends of global social development counterbalance each other, avoiding the immersion of humanity both in absolute totalitarianism and absolute anarchism. The self-regulation of a global social system called "humanity" seems to be balancing between these extremes (Branskij, Pozharsky, 2012).

An important consequence of this balancing is the balancing of society between the cult of production of values (the so-called "ideological" or "creative" society) and the cult of their consumption (the so-called "spiritless" or "consumer" society). A metaphorical way to describe these trends is the ancient story about the famous ancient philosopher Socrates (V in. BC) and his grumpy spouse Xantippa. The latter, according to legend, doused her great spouse with dirty wa- 
ter during his profound philosophical quest. Such an image is a good illustration of the priority that the international world-wide historical man in the street for many centuries has given to the consumption of values as opposed to their production. The conclusion is any scientific theory of values cannot fail to take into account the deep connection between production, distribution and consumption of values, and the fundamental value of ideology as an intersubjective (social) criterion of value.

At the present stage of development of science and philosophy, such a behavior of humanity can only be regarded as a symbol of the modern antisynergic world view, preferring to harmonize chaos and order (freedom and responsibility) with their irresponsible absolutisation (the struggle between systemic and chaotic ("clip") consciousness and thinking in modern literature). The point should be stressed, that both systemic and "clip" thinking (and their relationship) cannot be learned without systemic thinking, while systemic thinking with the help of "clip" thinking is completely beyond the grasp of the human mind.

\section{Acknowledgements}

The main results of the paper come from the findings received within the grant of the RF Ministry of Education and Science 2009-2014 on the topic: "Development of Synergetic Globalization Theory".

\section{REFERENCES}

Berdyaev, N. A. (1990). Istoki i smisl russkogo communizma (The Origin and Meaning of Russian Communism, in Russian). Academy of Sciences of the USSR.
Scientific Councel on prob. culture. Moscow: Science.

Branskij, V. P. (2014). Sinergetika i kosmologiya (Filosofskie osnovanija cosmologicheskoi modeli vselennoi) (Synergetics and Cosmology (Philosophical Foundations of the Cosmological Model of the Universe), in Russian). SPSU Bulletin, 17(4).

Branskij, V. P., Mikaylova I. G, Zobova M. R. (2017). Problema smisla zhizni i ego obshefilosofskoe i obshenauchnoe znachenie (The Problem of the "Meaning of Life" and its General Philosophical and General Scientific Importance, in Russian). SPb.: Publishing house of SPbGEU.

Branskij, V. P., Pozharsky, S. D. (Eds.). (2012). Sinergetocheskaja teorija cennostej (Synergetic Theory of Values, in Russian). SPb.: Publishing house "LEMA".

Branskij, V. V., Oganyan K. M., \& Pozharskiy, D. S. (2009). Sinergeticheskaya philosophiya istorii (Synergetic Philosophy of History, in Russian). Ryazan: CopyPrint.

Branskij, V., Oganyan, K. M., \& Oganyan, K. K. (2018). A New Line of Research: Synergetic Philosophy and Sociology of Personality. Wisdom, 10(1), 57-72.

Branskij, V. P. (1999). Isskustvo i filosofiya. Rol' filosofii $v$ formirovanii vospriyatiya $\mathrm{xu}$ dozhestvennogo proizvedeniya na primere istorii zhivopisi (Art and Philosophy. The Role of Philosophy in the Formation and Perception of a Work of Art on the Example of the History of Painting, in Russian). Kaliningrad: Amber tale. 
Brzezinski, Z. (1989). Bol'shoi proval: Rozhdenie i smert' kommunizma $v$ dvadtsatom veke (Big Failure: The Birth and Death of Communism in the Twentieth Century, in Russian). New York: Liosrty.

Fukuyama, F. (2007). Konec istorii i poslednii chelovek (The End of History and the Last Man, in Russian). (M. B. Levin, Trans.). Moscow: AST Ermak.

Katsura, A. V. (2016). Planetarnoe chelovechestvo: na krayu propasti (Planetary Humanity: on the Edge of a Precipice, in Russian). Moscow: Prospect.

Lenin, V. I. (1958). Polnoe sobranie cochinenii (Full Composition of Writings, in Russian). Ed. 4. Vol. 14.

Mao Zedong. (2007). Malen'kaya krasnaya knizhitsa (Little Red Book, in Russian). Moscow: Algorithm.

Marx, K. (1926). Kapital (Capital, in Russian). $2^{\text {nd }}$ ed. Moscow; Leningrad: State Ed.

Marx, K. (1982). Manifest kommunisticheskoi partii (Manifesto of the Communist Party, in Russian). Moscow: Politizdat.

Oganyan, K. M. (2007). Metodologicheskie problemi teorii globalizacii (Methodological Problems of the Synergetic Theory of Globalization, in Russian). Social Sciences and Modern times, 2, 150-155.

Oganyan, K. M. (2013). Zakonomernosti potrebleniya cennostei i potrebitelskie avtokolebaniya. Roli modi $\mathrm{v}$ potreblenii cennostei (Regularities of Consumption of Values and Consumer Automation. The Role of Fashion in the Use of Values, in Russian). Successes of Modern Natural Science, 2, 107-112.

Oganyan, K. M. (2017). Methodological Analysis of the Scientific Research. NOEMA,
XVI, 81-93.

Oganyan, K. M., Branskij, V. P. (2014). Zakon relevantnosti $i$ integracii idealov povedencheskix stereotipov (The Relevance and Integration Law of Behavioral Stereotype Ideals, in Russian). Vestnik KRSU, 14 (6), 70-79.

Oganyan, K. M., Oganyan, K. K. (2017). Sociologicheskoe issledovanie social'noi otvetstvennosti kak mezanizma upravleniya (Sociological Study of Social Responsibility as a Management Mechanism, in Russian). Sociology and Law, 2(36), 29-37.

Oganyan, K. M., Oganyan, K. K. (2017). Upravlenie social'no' otvetstvennost'yu v deyatel'nosti rossiiskogo biznes-soobshchestva (Managing Social Responsibility in the Activity of the Russian Business Community, in Russian). In $U r$ gent Problems of Sociology. Collection of scientific articles, (pp. 73-81). SPb.: SPbSEU.

Oganyan, K. M., Sahakyan, A. K., Pokrovskaya, N. N., \& Bakhshyan, A. Zh. (2013). Cennostnye orientacii $v$ trudovom povedenii $i$ kross-kulturnoe issledovanie trudovoi migracii (Value Orientations in Labor Behavior and Cross-Cultural Research of Labor Migration, in Russian). Yerevan: EDIT PRINT.

Oganyan, K.M., Branskij, V.P., Oganisyan, A.O., \& Djidjian, R.Z. (2018). Metodologicheskii analiz genezisa nauchnoi teorii: vidi estestvennonauchnogo znania i ikh vzaimosvazi. Ocherki o Leningradskoi ontologicheskoi i Erevanskoi logiko-argumentacionnoi shkolax (Methodological Analysis of the Genesis of 
a Scientific Theory: Types of Natural Science Knowledge and Their Relationship. Essays on the Leningrad Ontological and Yerevan Logical-Argumentative Schools, in Russian). SPb.: Publishing house of SPbGEU.

Popper, K. R. (1992). Otkritoe obshchestvo i ego vragi (Open Society and its Enemies, in Russian). (2 Vols.). (V. N. Sadovsky, Trans. \& Ed.). Moscow: Intern. Foundation "Cul't. Initsiative"- Soros foundation Open Society "Phoenix".

Popper, K. R. (1993). Nishcheta istoricizma (Poverty of Historicism, in Russian). Moscow: Progress.
Pyzh, V. V. (2017). The Role of UNESCO in Protecting Sports Integrity and Preserving Sports Ideals. Proceedings of the International Conference on Modern Research in Science and Technology, (pp. 596-607). Scientific public organization "Professional Science".

Pyzh, V. V. (2018). Doktrina upravlyaemogo xaosa i bezopasnosti sovremennoi Rossii (The Controlled Chaos Doctrine and Security of Modern Russia, in Russian). Modern Periodicals in the Context of Communicative Processes. The Future of Eurasia (Media and Political Discourse), 3(12), 38-52. SPb.: SPbSU. 